\title{
PEMBERDAYAAN KADER KESEHATAN TENTANG SOSIALISASI PALIATIF CARE " CENTAMA “ DI WILAYAH KERJA PUSKESMAS GRIBIG KECAMATAN GEBOG KABUPATEN KUDUS
}

\author{
Anita Dyah Listyarini ${ }^{1}$, Galia Wardha Alvita ${ }^{2}$ \\ Program Studi IImu Keperawatan STIKES Cendekia Utama Kudus \\ anitadyahlistyarini@gmail.com
}

\begin{abstract}
ABSTRAK
Perawatan paliatif bertujuan untuk mengurangi penderitaan pasien, meningkatkan kualitas hidupnya, serta memberikan dukungan kepada keluarganya. Perawatan paliatif adalah bukan untuk menyembuhkan penyakit, tetapi lebih pada peningkatan kualitas hidup serta yang ditangani pada perawatan paliatif tidak hanya pasien, melainkan juga keluarganya. Perawatan paliatif bertujuan untuk mengurangi penderitaan pasien, meningkatkan kualitas hidupnya, serta memberikan dukungan kepada keluarganya. Perawatan paliatif adalah bukan untuk menyembuhkan penyakit, tetapi lebih pada peningkatan kualitas hidup serta yang ditangani pada perawatan paliatif tidak hanya pasien, melainkan juga keluarganya. Metode yang digunakan dalam pengabdian masyarakat ini adalah obsevasional analitik menggunakan sampel sebanyak 22 perwakilan kader kesehatan di wilayah kerja puskesmas Gribig kecamatan Gebog kabupaten Kudus. Pemilihan sampel dilakukan berdasarkan rondom sampling. Tehnik pengambilan data primer dilakukan melalui wawancara tentang perawatan paliatif. Evaluasi dilaksanakan dengan pre dan pos tes tentang materi perawatan paliatif, dari pertanyaan pre dan post didapatkan ada peningkatan nilai pemahaman peserta antara pre tes dan pos tes. Hasil dari pengabdian masyarakat ini, sebagian besar $(80 \%)$ peserta kader kesehatan nilainya meningkat dari nilai pre tes rata-rata 5,8 menjadi nilai rata-rata post test 8,2.
\end{abstract}

Kata kunci : Perawatan paliatif, penyakit kronis, kader kesehatan

\begin{abstract}
Paliative care patients, aimed to reduce suffering improve the quality of his life, and providing support for his family. Palliative care is not cure diseases, but more on improveing the quality of life and handled in not only, palliative care patients but also his family palliative care patients, aimed to reduce suffering improve the quality of his life, and providing support for his family. Palliative care is not to cure diseases, but more on improving the quality of life and handled in not only, palliative care patients but also his family. Methods used in community devotion is observasional analytic using samples from 22 representatives in the work area of health care provider in the Puskesmas Gribig Kecamatan Gebog Kabupaten Kudus. Is based on sampling rondom sampling. The technique of primary data
\end{abstract}


was conducted through interviews about his palliative care. Evaluation pre be and in matter test about his palliative care, pre questions and post is the understanding of participant or the enhancement of value betwees and in pre test. The public was the result of devotion, most (80\%) participants health care provider value increased from the test are the average pre 5,8 average post test 8,2 .

Keywords : palliative care, cronic disease, health care provider 


\section{PENDAHULUAN}

Perawatan paliatif adalah perawatan pada seorang pasien dan keluarganya yang memiliki penyakit yang tidak dapat disembuhkan dengan cara memaksimalkan kualitas hidup pasien serta mengurangi gejala yang mengganggu, selain itu juga melalui pengurangan nyeri, dengan memperhatikan aspek psikologis dan spiritual pasien maupun keluarga. Perawatan ini juga menyediakan sistem pendukung untuk menolong keluarga pasien dalam menghadapi kematian dari anggota keluarga yang dicintai sampai dengan masa berkabung [1].

Perawatan paliatif memberikan pendekatan kesehatan terpadu yang bersifat aktif dan menyeluruh, yaitu pendekatan multidisiplin yang terintegrasi antara dokter, perawat, fisioterapis, petugas sosial medis, psikolog, ahli gizi, rohaniawan, relawan, serta profesi lain yang diperlukan. Adapun latar belakang diperlukannya perawatan paliatif adalah karena meningkatnya jumlah pasien dengan penyakit yang belum dapat disembuhkan (baik pada dewasa maupun anak), seperti penyakit kanker, penyakit paru obstruktif kronis, stroke, parkinson, gagal jantung, gagal ginjal terminal, dan lain-lain [2].

Perawatan paliatif bertujuan untuk mengurangi penderitaan pasien, meningkatkan kualitas hidupnya, serta memberikan dukungan kepada keluarganya. Jadi, tujuan utama perawatan paliatif adalah bukan untuk menyembuhkan penyakit, tetapi lebih pada peningkatan kualitas hidup serta yang ditangani pada perawatan paliatif tidak hanya pasien, melainkan juga keluarganya. Meski pada akhirnya pasien meninggal, yang terpenting sebelum meninggal, pasien sudah siap secara psikologis dan spiritual, dan tidak stres menghadapi penyakit yang dideritanya. Ketika menghadapi fase akhir hayat, diharapkan pasien akan mendapatkan kondisi die in dignity (husnul khotimah).

Kualitas hidup merupakan target yang ingin dicapai pada perawatan paliatif. Kualitas hidup pasien adalah keadaan pasien yang dipersepsikan sesuai konteks budaya dan sistem nilai yang dianutnya, termasuk tujuan 
hidup, harapan dan niatnya. Dimensi dari kualitas hidup adalah kemampuan fisik dan fungsional dalam beraktivitas, kesejahteraan keluarga, ketenangan spiritual, fungsi sosial, kepuasan terhadap pengobatan (termasuk masalah keuangan), orientasi masa depan, kehidupan seksual, termasuk gambaran terhadap diri sendiri dan fungsi dalam bekerja [2].

Prinsip-prinsip perawatan paliatif adalah menghargai setiap kehidupan, menganggap kematian sebagai proses yang normal, tidak mempercepat atau menunda kematian, menghargai keinginan pasien dalam mengambil keputusan, menghilangkan nyeri dan keluhan lain yang mengganggu, serta mengintergrasikan aspek psikologis, sosial, dan spiritual dalam perawatan pasien dan keluarga, menghindari tindakan medis yang sia-sia, memberikan dukungan yang diperlukan agar pasien tetap aktif sesuai dengan kondisinya sampai akhir hayat, serta memberikan dukungan kepada keluarga dalam masa duka cita.

Perawatan paliatif bertujuan untuk mengurangi penderitaan pasien, meningkatkan kualitas hidupnya, serta memberikan dukungan kepada keluarganya. Jadi, tujuan utama perawatan paliatif adalah bukan untuk menyembuhkan penyakit, tetapi lebih pada peningkatan kualitas hidup serta yang ditangani pada perawatan paliatif tidak hanya pasien, melainkan juga keluarganya. Persetujuan dari pasien dan atau keluarganya adalah mutlak diperlukan sebelum perawatan dimulai. Perawatan paliatif dilakukan melalui rawat inap, rawat jalan, dan kunjungan /rawat rumah. Pasien dapat memilih tempat dilakukannya perawatan. Misalnya apabila seorang pasien dalam kondisi terminal menginginkan untuk diberikan perawatan di rumah, maka perawatan paliatif ini dapat dilakukan melalui perawatan rumah (home care).

Salah satu visi Kementerian Kesehatan Republik Indonesia adalah memandirikan masyarakat untuk hidup sehat dengan misi membuat rakyat sehat. Guna mewujudkan visi dan misi tersebut berbagai program kesehatan telah dikembangkan termasuk pelayanan kesehatan di rumah. 
Pelayanan kesehatan di rumah (home care) adalah pelayanan keperawatan yang diberikan kepada pasien di rumahnya, yang merupakan sintesa dari pelayanan keperawatan komunitas dan keterampian teknikal tertentu yang berasal dari spesalisasi kesehatan tertentu, yang berfokus pada asuhan keperawatan individu dengan melibatkan keluarga dengan tujuan menyembuhkan, mempertahankan dan meningkatkan kesehatan fisik, mental/ emosi pasien.

\section{METODE PELAKSANAAN}

Metode yang digunakan dalam pengabdian masyarakat ini adalah obsevasional analitik menggunakan sampel sebanyak 22 perwakilan kader kesehatan di wilayah kerja puskesmas gribig kecamatan gebog kabupaten kudus. Pengabdian ini dilakukan pada bulan Februari 2020. Pemilihan sampel dilakukan berdasarkan romdam sampling. Tehnik pengambilan data primer dilakukan melalui wawancara tentang perawatan paliatif.

Sosialisasi ketrampilan diberikan dalam bentuk teori, praktik dan simulasi. Pendampingan dengan memberikan pelatihan kemampuan kader kesehatan dalam memberikan support system pada keluarga dengan kasus penyakit kronis.

Kegiatan pengabdian ini menggunakan metode ceramah, tanya jawab dan demontrasi dalam memberikan materi menggunakan metode ceramah tentang paliatif care. Langkah-langkah yang digunakan dalam pelaksanaan pengabdian ini, diantaranya ; diawali dengan proses perijinan di kepala puskesmas setempat dengan membawa surat tugas dari ketua stikes cendekia utama kudus; melakukan sosialisasi terkait kegiatan pengabdian kepada kader kesehatan puskesmas; melakukan skrining pengetahuan dan kemampuan kader tentang paliatif care;melakukan simulasi proses perawatan paliatif care; peneliti dan para kader kesehatan mendemontrasikan tehnik komunikasi dan konseling paliatif care; melaksanakan evaluasi proses dan diskusi berkaitan dengan 
materi paliatif care; peneliti memberikan rencana dan program tindak lanjut kepada ketua kader kesehatan puskesmas; Evaluasi dilaksanakan dengan pre dan pos tes tentang materi perawatan paliatif, dari pertanyaan pre dan post didapatkan ada peningkatan nilai pemahaman peserta antara pre tes dan pos tes.

\section{HASIL DAN PEMBAHASAN}

Kegiatan pengabdian pada masyarakat tentang perawatan paliatif pada pasien dengan penyakit kronis secara garis besar keberhasilan kegiatan ini sudah tercapai. Materi yang disampaikan dapat diterima dan dapat dipahami, serta mendapat respon dari peserta yang ditandai dengan adanya pertanyaan-pertanyaan yang kuncul, secara umum peserta memahami dan mampu mengaplikasikan perawatan paliatif dan penerapannya di masyarakat yang memiliki penyakit kronis. Kegiatan pengabdian masyarakat diwilayah kerja puskesmas gribig mendapatkan respon baik dan kader sangat antusia. Secara umum hasil pengabdian meliputi beberapa aspek pencapaian yaitu : 1) ketercapaian tujuan kegiatan pengabdian masyarakat tentang peningkatan kemampuan kader dalam memahami perawatan paliatif dengan benar dan sudah baik, semua persiapan dan materi yang direncanakan dapat tersampaikan dan didukung dengan hasil pembuktian evidence based yang dilakukan pengabdi secara langsung. 2) Ketercapaian target materi pada kegiatan pengabdian masyarakat ini cukup baik, karena materi telak tersampaiakn secara keseluruhan sebanyak 98\%. 3) Kemampuan peserta dilihat dari pemahaman paliatif yang diberikan oleh pemateri. Aplikasi perawatan paliatif ditingkat kader kesehatan dan natinya akan disosialisasikan ke masyarakat di wilayah kerja puskesmas gribig kabupaten kudus. 

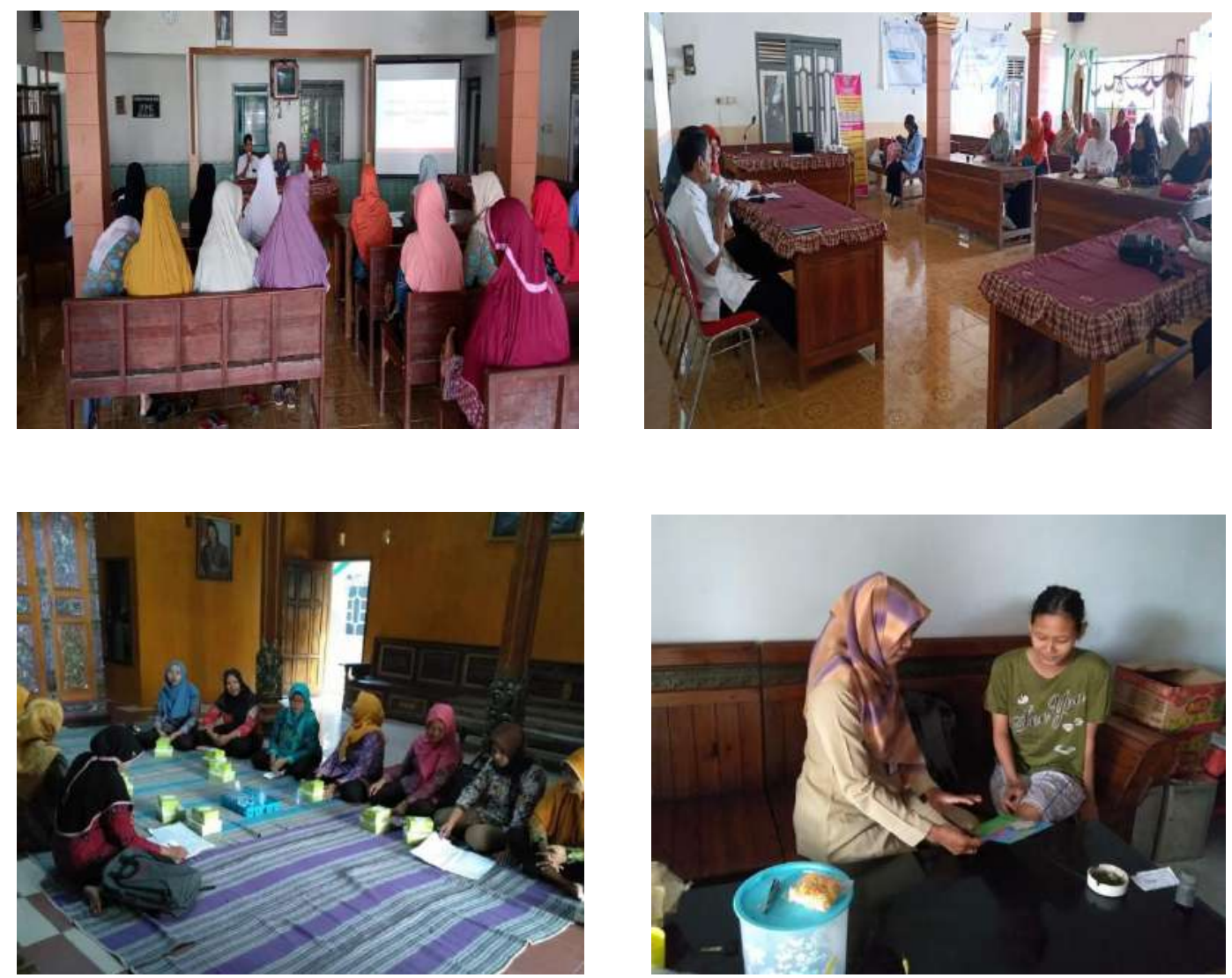

Gambar 1. Pelaksanaan pengabdian masyarakat sosialisasi paliatif care di wilayah Puskesmas Gribig

Pelaksanaan kegiatan pengabdian pada masyarakat terdapat factor pendukung dan penghambat yaitu : 1) untuk factor pendukung adanya respon positif dari pihak puskesmas dan kader kesehatan dalam pelaksanaan kegiatan sosialisasi perawatan paliatif dan tersedianya sarana dan prasarana dengan baik. 2) untuk faktor penghambat dalam pelaksanaan kegiatan evaluasi tidak dapat dilakukan untuk pendampingan kader paliatif untuk kunjungan kerumah warga secara keseluruhan mengevaluasi pemahaman perawatan paliatif hal ini dikarenakan kurangnya waktu dan tenaga.

\section{SIMPULAN}

Pelaksanaan pengabdian masyarakat dalam rangka meningkatkan kemampuan kader kesehatan dalam pemahaman kasus kasu penyakit 
kronis yang mengarah pada perawatan paliatif dapat disimpulkan berhasil sampai tahap kemampuan untuk mengaplikasikan. Keberhasilan ini ditunjukkan antara lain oleh : Adanya kesesuaian materi dalam mengatasi masalah di masyarakat dimana masyarakat khususnya masyarakatndan keluarga dengan kasus-kasus penyakit kronik dan penyakit terminal mampu memahami dan mengaplikasikan perawatan paliatif di rumah yaitu adanya respon yang positif dari peserta kader kesehatan yang ditunjukkan dengan pertanyaan dan tanggapan yang diberikan selama pengabdian. Sebagian besar $(80 \%)$ peserta kader kesehatan nilainya meningkat dari nilai pre tes rata-rata 5,8 menjadi nilai post test 8,2 .

\section{UCAPAN TERIMAKASIH}

1. Program Pengabdian masyarakat ini dibiayai oleh STIKES Cendekia Utama Kudus dengan Surat Perjanjian Kontrak Pengabdian Masyarakat (SPK-PM) Nomor: 054/SK-PI/LPPM-STIKES CU/II/2020 Tanggal 25 Februari 2020

2. Puskesmas Gribig Kecamatan Gebog Kabupaten Kudus yang telah memberikan ijin sehingga program pengabdian masyarakat ini berjalan dengan baik dan lancar.

\section{DAFTAR PUSTAKA}

1. Allender, Judith Ann, \& Spradley, Barbara Walton. (2011). Community Health Nursing: Concepts and Practice. $7^{\text {th }}$ edition. Philadelphia : Lippincott.

2. Anonim, 2013. Profil Dinas Kesehatan Kudus.

3. Friedman M. Marilyn, etc, (2013), Family Nursing, Research, Theory, and Practice, Fifth Edition, Philadelphia : Printice Hall

4. Kozier, E, Blais and Wilkinson (2010). Fundamental of Nursing consepts, proses, practisce, St Louis; The Mosby Year Book Inc 
5. Siegler, Eugenia L, MD and Whitney Fay W, PhD, RN., FAAN , alih bahasa Indraty Secillia, 2012. Kolaborasi Perawat-Dokter; Perawatan Orang Dewasa dan Lansia, EGC. Jakarta

6. Stanhope, M. \& Lancaster, J. (2014). Community health nursing : Promoting health of agregates, families and individuals. (5 th ed). St.Louis: Mosby, inc.

7. ....................2009. Petunjuk Teknis Perawatan Pasien Hipertensi dan Stroke Provinsi Jawa Tengah

8. ....................2012. Rencana Strategis Dinas Kesehatan Kudus 2011-2017.

9. …................, 2017. Profil Puskesmas Gribig Kabupaten Kudus.

10. ...................., 2017. Laporan Penanggung jawab Puskesmas Gribig Kecamatan Gebog Kabupaten Kudus. 